\title{
South Africa awaits decision on new science ministry
}

Cape Town. Now that the African National Congress (ANC) has gained its expected majority in last week's election, the concerns of South Africa's scientific community have become re-focused on whether the government of national unity will include a minister of science and technology.

This decision will be taken shortly by the ANC's national executive committee (NEC). If the outcome is positive, the critical question will be who president-elect Nelson Mandela appoints to the position when he announces the new cabinet at his inauguration in Pretoria next week.

The ANC takes pride in the fact that it is the world's first liberation movement to have drafted a science policy before coming into power. This is partly due to the efforts of NEC member Mohammed Valli Moosa, a strong proponent of the new ministry, whose creation is supported by both the scientific community and the private sector.

As the only scientist near the top of the ANC's list of candidates for the National Assembly, Moosa is also the most likely incumbent. A graduate of the University of Durban-Westville, he taught mathematics and physics for four years before becoming a full-time ANC activist in the early 1980s.

But cabinet positions will be distributed according to the support achieved by the various political parties in the elections. As a result, the prospective science and technology portfolio could alternatively be offered out to either Theo Alant of the National Party, an applied mathematician who is currently deputy minister of finance, or to Zach de Beer of the Democratic Party, a former physician who held a senior position in the Anglo-American Corporation before becoming the party's leader.

One advantage of creating a new ministry is that it will not be required to inherit any civil servants from the old administration, and could therefore provide an avenue for bringing in new talent.

Roger Jardine, science and technology co-ordinator for the ANC, says that what- ever the outcome of the debate on the new ministry, South Africa will soon have "a much better co-ordinated science system, with clear-cut national goals linked to the reconstruction and development programme",

But whether South Africa ends up with a new ministry for science, or merely a new agency, responsibility for science and technology will be "structurally defined" in the new government, according to Brian Clark, president of the Council for Scientific and Industrial Research.

Rolfe Stumpf, president of the Human Sciences Research Council, says he is optimistic about future funding prospects. "If the ANC is at all serious about their reconstruction and development programme, they cannot afford to decrease expenditure on science and technology," he says.

Few South Africans who voted in the country's first democratic election last week were left unmoved by the patient enthusi-

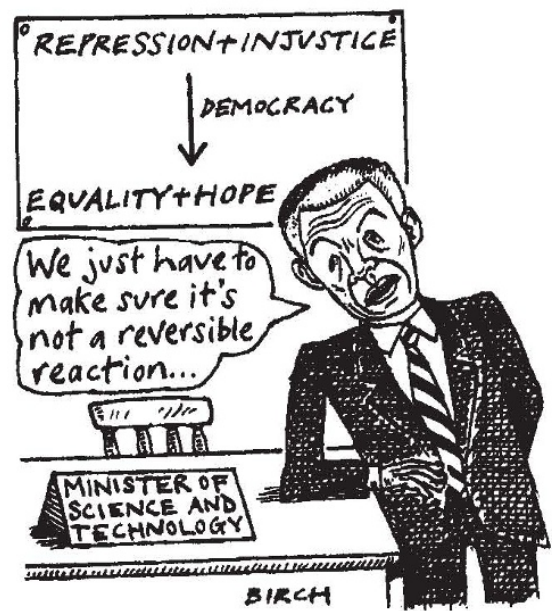

asm of the long queues of people, many of whom were casting their votes for the first time. Science policy was probably not uppermost in most of their minds. But, like many other matters, it has been more hotly debated in the past year than ever before.

Michael Cherry

\section{Chile backs ESO's rights in telescope dispute}

Munich. An extraordinary meeting of the European Southern Observatory (ESO) council agreed last week to send a delegation to Chile to discuss with the government the claims by a Chilean family that it is the rightful owner of the 725 square kilometre site for ESO's Very Large Telescope (VLT) at Mount Paranal.

The families' claims have resulted in a prolonged series of court hearings which threaten to prevent ESO from completing the building of the VLT, planned as the world's largest telescope, in Chile (see Nature 368, 676; 1994). ESO was given the land in 1988 by the Chilean government, and wants the government to take a more active role in settling the dispute.

Earlier last week the government moved in this direction, by confirming to mental organization, has immunity from local law in Chile. the courts that ESO, as an intergovern-

\section{German institute under fire over HIV-blood reports}

Munich. The head of the Paul Ehrlich Institute for Sera and Vaccines in Langen, near Frankfurt, became caught up in political cross-fire last week when he was criticized for accepting "six figure sums" from pharmaceutical companies for preparing reports on techniques for inactivating HIV in blood products.

Reinhard Kurth has denied the charges, which he claims are politically motivated, and aimed to discredit the health minister, rather than himself. He is suing his accuser, the Social Democratic Party's health spokesman Horst Schmidbauer, for libel.

Schmidbauer made his accusations shortly before a meeting last week of the parliamentary committee investigating the circumstances surrounding several cases of HIV-contaminated blood products which came to light last October.

Horst Seehofer, Germany's health minister, had responded to the scandal by announcing plans to dissolve the Bundesgesundheitamt (BGA) - six health institutes directly responsible to the ministry of health through a central administration in Berlin - after complaining that officers had not kept him informed of vital issues.

But Seehofer's opponents are seeking to weaken the political credibility he gained by this action by claiming that he has little effective control over the institutes for which he is responsible.

The Paul Ehrlich Institute, like the BGA, is directly responsible to the ministry of health. In the early 1980 s, it was the only institute in Germany with wide experience with retroviruses, and was approached for advice from blood product manufacturers worried about HIV contamination.

Between 1984 and 1985, Kurth and his colleagues - with approval of the ministry of health - prepared reports about the inactivation of the HIV virus in blood products for Behring, Armour Pharma, Immuno and DRK Institute Springe, as well as the Red Cross Blood Bank.

Kurth and Seehofer told the parliamentary committee that DM90,000 had been received for preparing the reports. One-fifth went to the ministry, and the rest was divided between Kurth and his co-workers.

But Schmidbauer claims that more money was involved, and argues that the ministry was wrong to have allowed researchers paid from public funds to carry out work for private companies.

Meanwhile Parliament has approved a new structure proposed by Seehofer for the BGA. This abandons the central administration, which had over 300 employees, and reorganizes the BGA into three institutes.

Alison Abbott 